Article

\title{
Physiological Behavior of the Aquatic Plant Azolla sp. in Response to Organic and Inorganic Fertilizers
}

\author{
Ehab Azab $1,2, *(1)$ and Abdel-fatah Salah Soror ${ }^{2}$ \\ 1 Biotechnology Department, Faculty of Science, Taif University, P. O. Box 888, Taif, 21974 Taif, Saudi Arabia \\ 2 Botany and Microbiology Department, Faculty of Science, Zagazig University, Zagazig, 44519 Sharkia, Egypt; \\ dr.abdelfatahsoror@gmail.com \\ * Correspondence: ehabazab@yahoo.com; Tel.: +966-530743728
}

Received: 23 June 2020; Accepted: 17 July 2020; Published: 21 July 2020

\begin{abstract}
The present investigation aims to evaluate the impacts of organic and inorganic fertilizers on the water parameters and physiological behaviors of an aquatic plant (Azolla sp.). The experiment used three groups: treatment with organic or inorganic fertilizer and a group with no fertilization as a control. Azolla sp. were grown in cement ponds that received different treatments. For water analysis, the obtained results clarified that fertilization resulted in no variation in the temperature or total hardness among different treatments. Organic fertilizer increased the dissolved phosphorus content, total hardness, and bicarbonate alkalinity, as well as the total phosphorus content, whereas inorganic treatment increased the $\mathrm{pH}$, total ammonia content, and total nitrogen content. Regarding the biochemical composition of Azolla sp., the chlorophyll content showed no variation among different treatment groups, while organic matter showed high variation among different treatment groups. The highest values for ash and fat content were recorded in control ponds. The highest protein content was found in organic treatment ponds. The addition of fertilizers led to an increase in the tissue contents of $\mathrm{N}$ and $\mathrm{P}$ compared to the control. This increase was highest when Azolla sp. was fertilized with organic fertilizer. The atomic N:P ratio was low in tissues subjected to either treatment compared with the control. The doubling time of Azolla sp. was decreased by fertilization. It is concluded that different fertilizer systems have significant effect on physico-chemical and biological parameters of water. Fertilization positively affects Azolla sp. growth. Organic fertilizer was more efficient for the growth of Azolla sp., so it can be considered as a source of biofertilizer and green manure in areas where it spreads.
\end{abstract}

Keywords: Azolla; organic fertilizer; inorganic fertilizer; biochemical composition

\section{Introduction}

To enhance the biological productivity of aquatic plants grown in ponds, both organic manure and inorganic chemical fertilizers can be used [1,2]. The application of fertilizers stimulates pond productivity through autotrophic pathways as well as heterotrophic pathways [3,4]. The major fertilizing elements are phosphorus and nitrogen, which are applied to fishponds in the form of inorganic fertilizer to stimulate algal growth to increase zooplankton production. Moreover, phosphate fertilizer is important for regulating the productivity of fishponds. It is considered to be the most critical single factor in the maintenance of pond fertility [5]. However, nitrogen is not often considered to be a limiting nutrient in pond productivity [6-8], partly because it is biologically fixed by nitrogen-fixing blue green algae and bacteria occurring in the pond system [9] or is abundant in the bottom sediment due to the accumulation of decomposing materials. It could be stated that inorganic fertilizers contain higher contents of nitrogen and phosphorus than organic fertilizers, leading to a higher water quality and dissolved oxygen content within $\mathrm{pH}$-moderating water [10]. Potassium and calcium can also 
be used as fertilizer elements. It could be stated that inorganic fertilizers have certain advantages compared with organic ones. Hence, inorganic chemical fertilizers are widely available, require low application rates, dilute easily in water and have well-defined compositions and high nitrogen contents.

Organic fertilizers play an important role in the conservation of soil, since they improve the organic matter level and increase long-term soil fertility, affecting plant growth [11-13]. The addition of organic fertilizer to water plays an important role in the enhancement of the chemical, physical, and biological properties of water $[14,15]$. According to the source of organic fertilizer, both the stability and quality of fertilizer are affected based on the raw material composition $[16,17]$. Since organic wastes can pollute the surrounding environment, its management will benefit soil as a source of organic fertilizer that benefits soil and water fertility, as well as keeping the environment clean. Organic fertilizers that are widely obtainable within the Sharkia region are chicken, cow, and duck wastes. Therefore, the use of organic fertilizers to improve both soil fertility and productivity is gaining importance [18].

Azolla pinnata (Azolla sp.) is a small aquatic fern grown in aquatic ecosystems in tropical and subtropical regions [19-21]. It prefers still water with little flow and clay sandy or fertile soils [22]. The genus Azolla sp. is usually included with the genus Salivinia in the family Saliviniaceae order Saliviniales, but it is separated into the family Azollaceae [23]. Azolla sp. fix atmospheric nitrogen in association with the cyanobacterium Anabaena azollae [24]. The combination of Azolla sp. and nitrogen-fixing algae leads to a high rate of productivity [25]. It can be used to replace part or all of the inorganic nitrogenous fertilizer required for rice production through Azolla-Anabaena symbiosis in which Azolla sp. fixes atmospheric nitrogen [26,27]. The high nutritional valve and protein content of Azolla sp. make it an important feed supplement for an assortment of animals [28]

It can be stated that fertilized fishponds are a suitable medium for Azolla sp. growth; however, Azolla sp. rapidly self-propagates and doubles its biomass in a few days (3-10 days) [29]. Azolla ferns are used for crop production in Asia and as a supplement to poultry diets due to their ability to fix 2-3 kg of nitrogen [24]. Azolla sp. has also attracted the interest of fish producers due to its high protein content [30].

Organic and inorganic pollutants that contaminate both soil and water can be accessed by plant roots causing contamination and requiring phytoremediation [31-34]. Sood et al. (2012) [35] illustrated the ability of the aquatic macrophytes Azolla sp. to phytoextract polluted contaminates as an environmentally friendly option for restoring polluted aquatic resources. [36] Liu et al. (2008) introduced Azolla sp. as an ecological life controller due to its high capacity to release oxygen and also as a carbon source of the blue-green algae Anabaena spp [37].

Fertilization increases chlorophyll, nutrient contents ( $\mathrm{N}$ and $\mathrm{P})$, biochemical composition, and growth rate of Azolla species. Adding fertilizers to Azolla sp. enhances its nutrition value [38]. Moreover, it can be used as a biological filter for purifying water as well as providing food and shelter to fish and invertebrates [39].

The aim of this study was to evaluate the influences of different fertilizers, like organic and inorganic fertilizers, on the physiological behavior of the aquatic plant Azolla sp. grown within ponds as well as the physico-chemical changes in water that received different kinds of fertilizer.

\section{Results}

\subsection{Physico-Chemical Analysis of Water}

Water is the fundamental and most critical requirement for the growth of Azolla sp. The data shown in Figure 1a indicate that there were no differences in water temperature among the different treatment groups (organic and inorganic fertilizers and the control). Figure 1a shows that the hydrogen ion concentration was on the alkaline side and varied among different treatments. The maximum value was recorded with inorganic treatment (8.88), whereas the lowest value was observed with organic fertilizer treatment (8.30). 

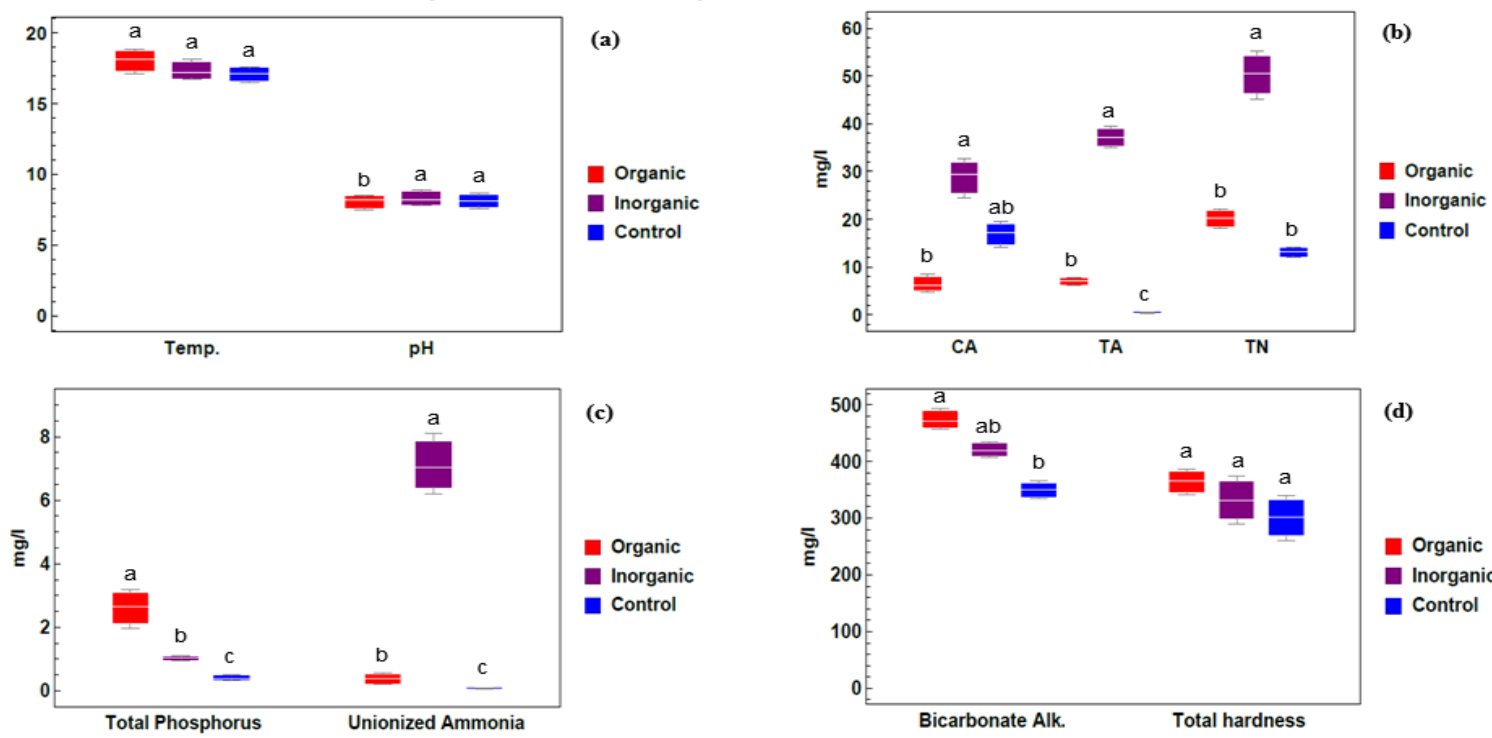

(d)
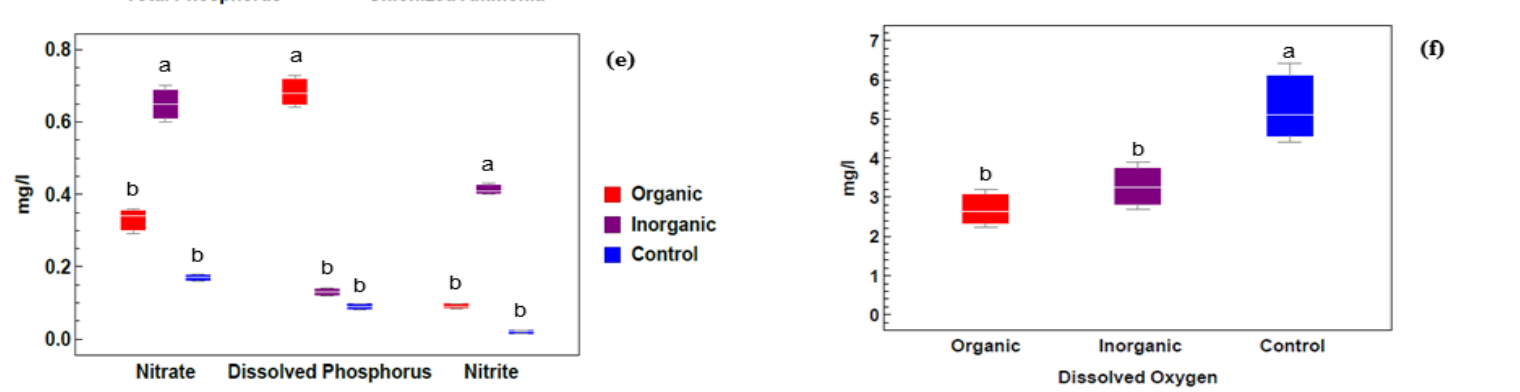

Figure 1. Physico-chemical parameters of water samples collected from different treatment groups: organic, inorganic and control. (a) Temperature, Hydrogen ion concentration; (b) CA (Carbonate Alkalinity), TA (Total Ammonia), TN (Total Nitrogen); (c) Total Phosphorus, Unionized Ammonia; (d) Bicarbonate alkalinity, Total hardness; (e) Nitrate, Dissolved Phosphorus, Nitrite; (f) Dissolved Oxygen. Different lowercase letters indicate significant differences between different treatments at $p \leq 0.05$.

As shown in Figure 1b, a higher carbonate alkalinity (CA) was found for the inorganic treatment group $(32.83 \mathrm{mg} / \mathrm{L})$ compared with the organic treatment $(6.6 \mathrm{mg} / \mathrm{L})$ and control $(19.50 \mathrm{mg} / \mathrm{L})$ groups and this was associated with a higher $\mathrm{pH}$, while lower carbonate alkalinity was associated with a lower $\mathrm{pH}$. On the other hand, the bicarbonate alkalinity (Bicarbonate Alk.) Figure 1d concentration was high in the organic treatment group $(471.33 \mathrm{mg} / \mathrm{L})$ and low in the control group $(350.00 \mathrm{mg} / \mathrm{L})$.

Figure $1 \mathrm{~b}$ also indicates that the total ammonia content (TA) had the highest value $(39.4 \mathrm{mg} / \mathrm{L})$ in the inorganic treatment group and the lowest value $(0.55 \mathrm{mg} / \mathrm{L})$ in the control group. Similarly, the unionized ammonia Figure 1c concentration was higher in the inorganic treatment group $(7.02 \mathrm{mg} / \mathrm{L})$ compared with the organic treatment $(0.39 \mathrm{mg} / \mathrm{L})$ and control $(0.07 \mathrm{mg} / \mathrm{L})$ groups. Highly significant variation was shown among different treatment groups. Moreover, as shown in Figure 1e, nitrite and nitrate concentrations were higher in the inorganic treatment group $(0.41$ and $0.65 \mathrm{mg} / \mathrm{L}$, respectively) and lower in the control group $(0.02$ and $0.17 \mathrm{mg} / \mathrm{L})$. In the same way, the total nitrogen content (TN) Figure $1 \mathrm{~b}$ and unionized ammonia Figure $1 \mathrm{c}$ in the water supporting Azolla sp. recorded their highest values in the inorganic treatment group and their lowest values in control group.

The total and dissolved phosphorus contents Figure 1c,e showed highly significant variations between the inorganic and organic treatment groups. The highest and lowest concentrations of dissolved phosphorus were $0.68 \pm 0.08$ and $0.09 \pm 0.01 \mathrm{mg} / \mathrm{L}$, and these were observed in the organic and control treatment groups, respectively. The higher total phosphorus content was measured in the organic treatment group $(2.65 \pm 0.43 \mathrm{mg} / \mathrm{L})$, and regarding the total hardness Figure $1 \mathrm{~d}$, the lowest and 
highest concentrations were $302.66 \pm 28.1$ and $366.00 \pm 15.6 \mathrm{mg} / \mathrm{L}$ in the control and organic treatment groups, respectively. From Figure 1f, we concluded that a higher value of dissolved oxygen was recorded in control ponds $(5.15 \pm 0.7 \mathrm{mg} / \mathrm{L})$, while lower values were found in organic treatment ponds $(2.63 \pm 0.3 \mathrm{mg} / \mathrm{L})$.

\subsection{Azolla sp. Analysis}

\subsubsection{Chlorophyll Determination}

Regarding the chlorophyll concentration in Azolla sp. samples, the data given in Figure 2, which were used as a stress indicator, clearly indicate that chlorophyll a and b did not vary significantly among different treatment groups, and the maximum value $(0.669 \mathrm{mg} / \mathrm{g})$ was recorded in the control treatment group while the minimum value $(0.519 \mathrm{mg} / \mathrm{g})$ was found in the organic group.

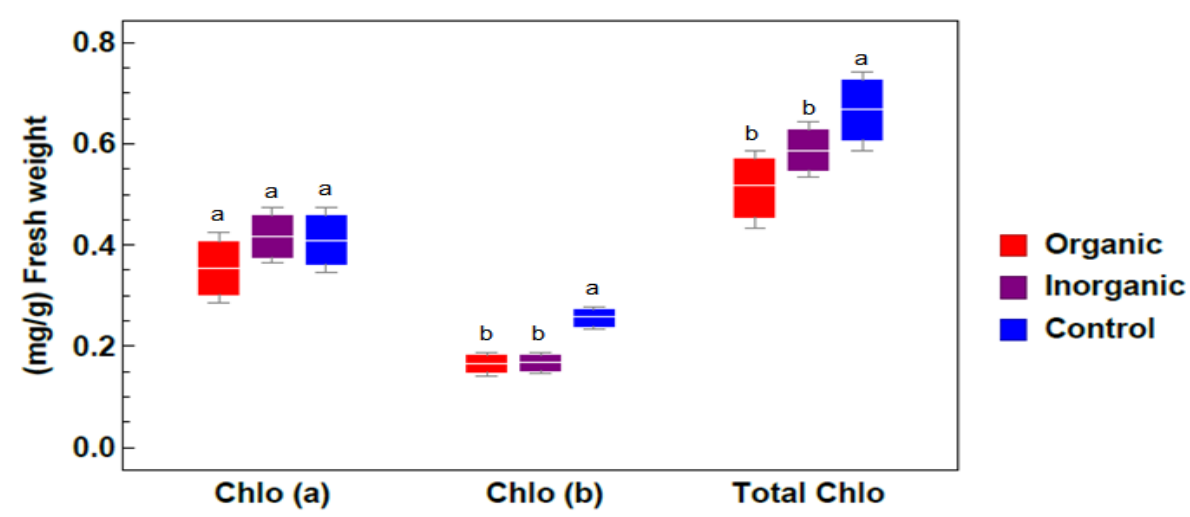

Figure 2. Impacts of different treatments on photosynthetic pigments in Azolla sp. plants. The photosynthetic pigments measured were chlorophyll a (Chlo a), chlorophyll b (Chlo b), and total chlorophyll (Total Chlo) (value $(\mathrm{mg} / \mathrm{g}) \pm$ the standard errors from three independent experiments under different treatments: organic, inorganic, and control). Different lowercase letters indicate significant differences between different treatments at $p \leq 0.05$.

\subsubsection{Biochemical composition of Azolla sp. samples subjected to different treatments}

The results represented in Figure 3 show that organic matter varied significantly among different treatment groups, since the organic matter concentration was $86.53 \%, 82.03 \%$, and $70.16 \%$ in the organic, inorganic, and control treatment groups, respectively. This can be seen by the percentage of protein content, since the highest protein content (30.25\%) was found in the organic treatment group, followed by $25.57 \%$ and $19.25 \%$ in the inorganic and control group, respectively, whereas the fat and ash contents were high in the control treatment group (4.36\% and $25.5 \%)$ compared with the inorganic and organic treatment groups (3.58\%, 17.04\%, and 3.06\%, 12.07\%, respectively; Figure 3). The highest protein content was found in the organic treatment group, followed by the inorganic and control groups. The fat content varied significantly $(p<0.05)$ among different treatment groups, and the highest values $(4.36 \%)$ were recorded in control ponds. 


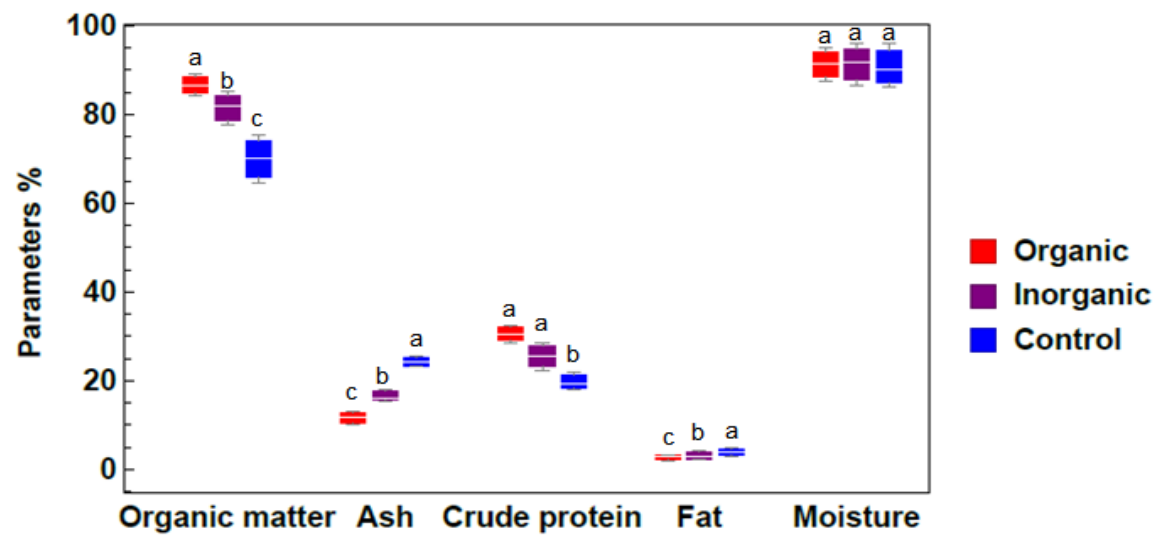

Figure 3. Biochemical composition of Azolla sp. samples exposed to different treatments (means \pm standard errors from three independent experiments under different treatments: organic, inorganic and control). Different lowercase letters indicate significant differences between different treatments at $p \leq 0.05$.

\subsubsection{Total Nitrogen and Total Phosphorus Contents}

Figure 4 shows that fertilization led to significant increases in both $\mathrm{N}$ and $\mathrm{P}$ in plant tissue content compared with the control. This increase was the highest when Azolla sp. was fertilized with chicken manure. The atomic N:P ratio in the tissues of both treatment groups was low (10.19 and 10.05) compared with the control (12.72), indicating a deficiency of $\mathrm{N}$ relative to P. Fertilization led to a decrease in the N:P ratio, where Azolla sp. absorbed more P than in control ponds.

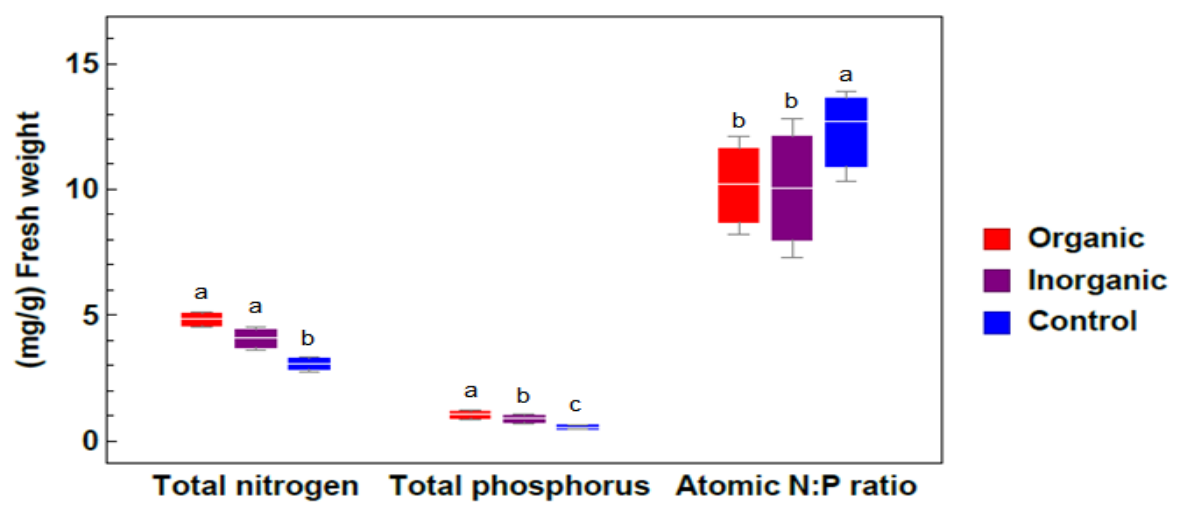

Figure 4. The variation of the total nitrogen (TN), total phosphorus (TP), and N: P ratio in tissues of Azolla sp. exposed to different treatments (means \pm standard errors from three independent experiments under different treatments: organic, inorganic and control). Different lowercase letters indicate significant differences between different treatments at $p \leq 0.05$.

\subsubsection{Relative Growth Rate}

In general, the two fertilized treatments showed increases in biomass compared with the control group, with the highest values shown for organic treatment for fresh weight (Figure 5a) and dry weight (Figure 5b). Figure $5 c$ clarifies the decrease in the doubling time of Azolla sp. by using different fertilizers, ranging from an average of $7 \mathrm{~d}$ to $9.2 \mathrm{~d}$ for organic and inorganic treatments, respectively. The doubling time $\left(\mathrm{D}_{\mathrm{t}}\right)$ was $23.5 \mathrm{~d}$ in control ponds. The highest biomass values for fresh weight $(698.26 \mathrm{~g})$, dry weight $(60.88 \mathrm{~g})$, and relative growth rate $(0.406 \mathrm{~g} / \mathrm{g} / \mathrm{d})$ were observed in organic treatment ponds (Figure $5 \mathrm{~d}$ ). Moreover, there were no significant $(p>0.05)$ statistical differences in this area between the two fertilization treatments. 

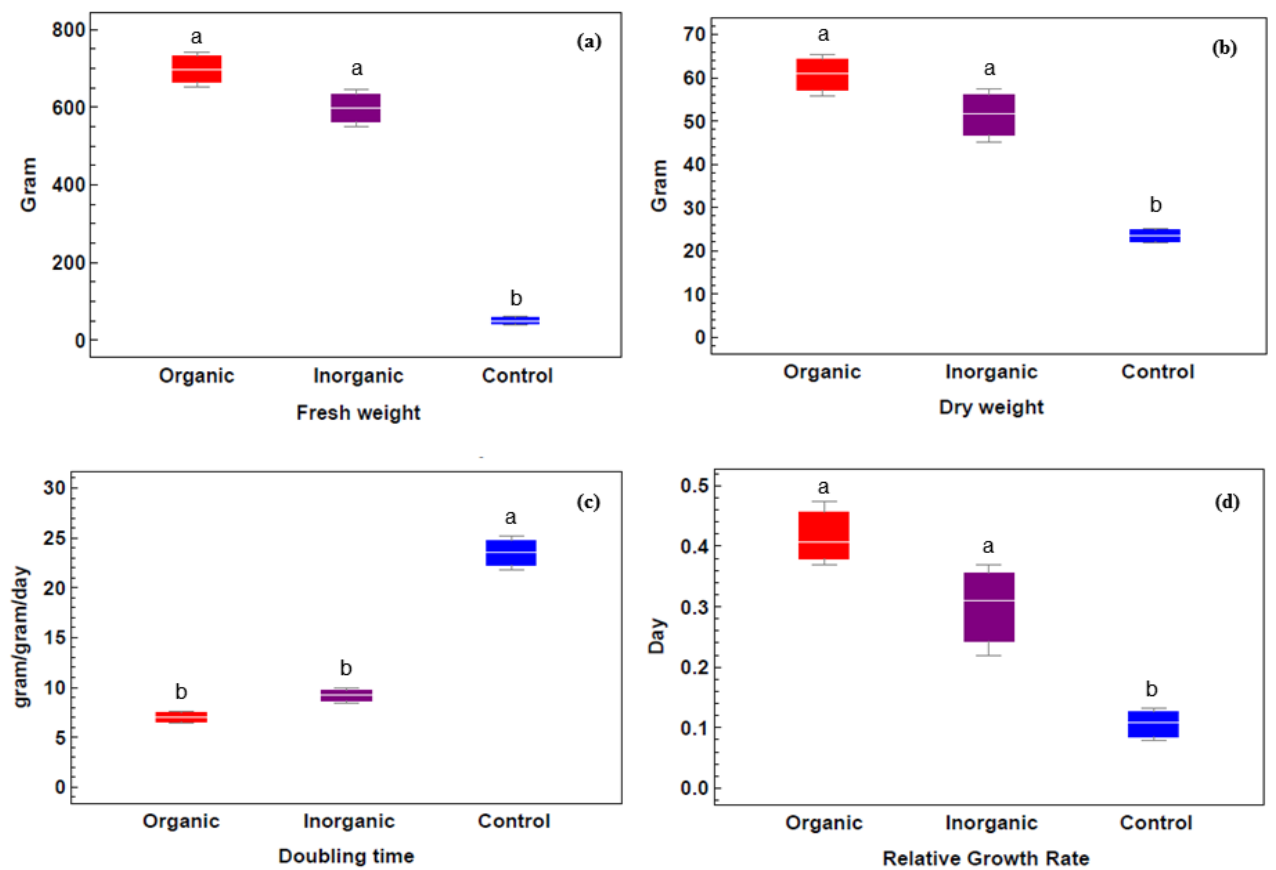

Figure 5. Relative growth rate and doubling time of Azolla sp. samples exposed to different treatments. (a) Fresh weight, (b) dry weight, (c) doubling time, and (d) relative growth rate of Azolla sp. samples under different treatments (means \pm standard errors from three independent experiments under different treatments: organic, inorganic and control). Different lowercase letters indicate significant differences between different treatments at $p \leq 0.05$.

\subsection{Correlation Coefficients}

The correlations between each pair of variables are illustrated in Table 1. Positive correlations were identified between $\mathrm{NH}_{4}$ (ammonium) and $\mathrm{NH}_{3}$ (ammonia) $(r=0.996 ; p=0.000), \mathrm{NO}_{2}$ (nitrite) and $\mathrm{NO}_{3}$ (nitrate) $(r=0.982 ; p=0.000), \mathrm{pH}$ and $\mathrm{CO}_{3}(r=0.978 ; p=0.000)$, fresh and dry weights $(r=1.000 ; p=0.000)$, and total nitrogen and protein $(r=1.000 ; p=0.000)$. The relationship between relative growth rate (RGR) and doubling time $\left(D_{t}\right)$ was negative $(r=-0.982 ; p=0.000)$. On the other hand, there were no correlations between total phosphorus (TP) and total nitrogen (TN) $(r=0.266$; $p=0.851)$, dissolved oxygen (DO) and $\mathrm{NH}_{3}(r=0.365 ; p=0.762)$, DO and TN $(r=0.451 ; p=0.702)$, and $\mathrm{DO}$ and $\mathrm{NO}_{2}(r=0.439 ; p=0.711)$.

Table 1. Pearson correlation coefficients $(r)$ between each pair of different parameters.

\begin{tabular}{ccc}
\hline Item & $\boldsymbol{r}$ & $\boldsymbol{p}$ \\
\hline $\mathrm{NH}_{4}{ }^{+} \& \mathrm{NH}_{3}$ & 0.996 & 0.000 \\
$\mathrm{NO}_{2}{ }^{-} \& \mathrm{NO}_{3}{ }^{-}$ & 0.982 & 0.000 \\
${\mathrm{pH} \& \mathrm{CO}_{3}{ }^{-2}}_{\mathrm{TP} \& \mathrm{TN}}$ & 0.978 & 0.000 \\
$\mathrm{DO} \& \mathrm{NH}_{3}$ & -0.266 & 0.851 \\
$\mathrm{DO} \& \mathrm{TN}^{-}$ & -0.365 & 0.762 \\
$\mathrm{DO} \& \mathrm{NO}_{2}{ }^{-}$ & -0.451 & 0.702 \\
$\mathrm{RGR} \& \mathrm{D}_{\mathrm{t}}$ & -0.439 & 0.711 \\
Fresh \& dry weight & -0.982 & 0.000 \\
TN \& protein & 1.000 & 0.000 \\
\end{tabular}

Significant values at: $p<0.05,(n=36)$. Data showed the correlation coefficients $(r)$ and probability $(p)$ between each pair of variables. $\mathrm{NH}_{4}{ }^{+}$; Ammonium; $\mathrm{NH}_{3}$ : Ammonia; $\mathrm{NO}_{2}{ }^{-}$: Nitrite; $\mathrm{NO}_{3}{ }^{-}$: Nitrate; $\mathrm{pH}$ : Hydrogen ion concentration; $\mathrm{CO}_{3}{ }^{-2}$ : Carbonate; TP: Total Phosphorus; TN: Total Nitrogen; DO: Dissolved Oxygen; RGR: relative growth rate; $\mathrm{D}_{\mathrm{t}}$ : doubling time. 


\section{Discussion}

According to the physico-chemical analysis of water, the hydrogen ion concentration was on the alkaline side in different treatments, which may be due to the negative effect of organic manure on the $\mathrm{pH}$ value of water, whereby the heterotrophic activities of aerobic bacteria reduce the $\mathrm{pH}$ through respiration through organic manure decomposition and serve as a continuous source of carbon dioxide, which leads to a decline in $\mathrm{pH}$ [40]. According to Utomo et al., 2019 [41], the $\mathrm{pH}$ in the studied ponds is suitable for the growth of Azolla sp., where productivity is maximized in water with a $\mathrm{pH}$ of 3.5-8. The bicarbonate alkalinity concentration was high in ponds treated with organic fertilizer due to the increased carbon dioxide production, resulting from organic fertilizer decomposition by bacteria. Carbon dioxide reacts with calcium and magnesium in water, forming calcium and magnesium bicarbonate in great volumes compared with inorganic treatments [41,42].

The values of different forms of nitrogen in the inorganic treatment group were increased compared with the organic and control groups. This may be a result of the high nitrogen content from the addition of urea, which dissolves in water and is rapidly converted to ammonia [43]. A higher total phosphorus content occurred in the organic treatment group, which may be due to organic fertilizer decomposition by bacteria which releases both forms of phosphorus [44]. Regarding the total hardness, the results are in accordance with Das et al. (2005), and Kamal et al. (2008) [45,46], who recorded increases in the total hardness and alkalinity with the addition of organic fertilizer. A lower value of dissolved oxygen was recorded with the organic treatment. This could be attributed to the lower dissolved oxygen content of the ponds with dense cover of floating plants than those with less cover of floating plants, which explains the increase in dissolved oxygen in the control compared with organic and inorganic treatment groups [47].

The maximum chlorophyll concentration in Azolla sp. samples occurred in the control group, while the minimum value was found in the organic treatment group. This may be due to the increased plant density (growth) in fertilized ponds which leads to dilution or distribution of chlorophyll pigment through the leaves [48,49]. Ren et al. (2017) [50] reported that with an increase in plant density, chlorophyll a and $\mathrm{b}$ contents significantly decreased, leading to a decreased photosynthetic rate during plant growth. These results are similar to those obtained for this study.

Organic matter showed highly significant variations among different treatments. Since the ash content was high in the control treatment compared with the inorganic and organic treatment groups, it seems that the effect of fertilization on the ash content was statistically significant. Similar responses were also found by Hazary (2015) [51], who reported that the ash content decreased with an increasing level of phosphorus. The highest protein content was found in the organic treatment group. It can be concluded that Azolla sp. plants can synthesize nitrogen compounds and transform them into protein form, even though the growing medium contains a low level of nitrogen. This may be due to the ability of Azolla sp. ferns to fix nitrogen in the presence of nitrogenase during symbiosis with Anabaena blue green algae as reported by [52]. In conclusion, different studies have illustrated that the environmental conditions affect the biochemical composition of Azolla sp. plants. Moreover, different species of Azolla $s p$. could have different compositions [53-55].

An N:P ratio lower than 8-16 indicates an N limitation, as illustrated in [56,57]. The lower $\mathrm{N}$ and $\mathrm{P}$ contents in the control group indicate the importance of nutrient availability for the growth of Azolla sp. Our results show that Azolla sp. is limited by N. The high contents of $\mathrm{N}$ and $\mathrm{P}$ in the tissues of Azolla sp. exposed to organic treatment indicate that this species is more capable of taking up these nutrients when exposed to organic fertilizer compared inorganic fertilizer $[27,58]$. The doubling time was very slow in control ponds (23.5 days), since [59] described that a $D_{t}$ of 4-6 days is fast, 7-9 days is moderate, and more than nine days is slow.

In general, the two fertilized treatments were associated with an increase in biomass compared with the control group, with the highest values occurring with the organic treatment. There was no significant $(p>0.05)$ statistical difference between the two fertilized treatments. Azolla sp. growth increased following treatment with organic and inorganic fertilizers combined with high values of 
$\mathrm{N}$ and $\mathrm{P}$ content in the tissues. Similar results were obtained by [41] for organic and [60] inorganic fertilizer. Those authors mentioned that increased biomass of macroalgae tissues was observed after fertilization with $\mathrm{N}$ and $\mathrm{P}$.

\section{Materials and Methods}

The experiment was conducted in nine concrete ponds. The volume of each pond was $12.5 \mathrm{~m}^{3}$ (5 m length; $2.5 \mathrm{~m}$ width; $1.0 \mathrm{~m}$ height). The ponds were located at the Aquaculture Research Laboratory, Abbassa, Abo-Hammad, Sharkia, Egypt. Firstly, ponds were drained and cleaned, and freshwater was added to a depth of $0.3 \mathrm{~m}$. Thus, the volume of added water was $3.75 \mathrm{~m}^{3}=3750 \mathrm{~L}$. The experiment began in 1st November 2019 and continued for 30 days.

Azolla sp. plants were collected from irrigation canals and washed with $2 \%$ Clorox to kill attached organisms. The plants were then put inside the ponds to cover about $10 \%$ of the pond surface area. Azolla sp. was grown in three pond groups. The first group received $1.0 \mathrm{~kg}$ of poultry manure weekly as an organic fertilizer. The nutrient contents of poultry manure are shown in Table 2. The second group received inorganic fertilizer containing $20 \mathrm{mg} / \mathrm{L}$ urea $(46.5 \% \mathrm{~N})$ and $1.75 \mathrm{mg} / \mathrm{L}$ pure phosphorus (P) $\left(45.0 \% \mathrm{P}_{2} \mathrm{O}_{5}\right)$, and finally, plants were grown in ponds without any fertilization as a control.

Table 2. Nutrient contents of poultry manure.

\begin{tabular}{cccccccc}
\hline \multirow{2}{*}{ Organic Fertilizer } & \multicolumn{3}{c}{ Macronutrients } & \multicolumn{4}{c}{ Micronutrients } \\
\cline { 2 - 8 } Contents & $\mathbf{N} \%$ & $\mathbf{P} \%$ & $\mathbf{K} \%$ & Fe (ppm) & Zn (ppm) & Cu (ppm) & Mn (ppm) \\
& 1.93 & 0.90 & 1.23 & 1150.6 & 185 & 33.3 & 222 \\
\hline
\end{tabular}

\subsection{Sampling Points and Analysis}

Three samples of Azolla sp. were collected weekly for each treatment (one sample from each pond) during one month to analyze the chlorophyll a and b contents, conduct a proximate chemical analysis (moisture, protein, fat, and ash \%) in the dried Azolla sp., and measure the growth rate of Azolla sp. Water samples were also collected weekly to analyze the physico-chemical properties of water ponds throughout the investigation period.

Physico-Chemical Analysis of Water

The water temperature and dissolved oxygen were detected using an Oxygen-Thermometer apparatus (YSI model 58, Yellow Spring Instrument Co., Yellow Springs, Ohio, USA) [61]. The pH was measured using a glass electrode $\mathrm{pH}$-meter [61]. The total alkalinity $(\mathrm{mg} / \mathrm{L})$ and total hardness $(\mathrm{mg} / \mathrm{L})$ were determined using the method described by [62]. The total ammonia concentration was measured [61]. The nitrite-nitrogen $\left(\mathrm{NO}_{2}-\mathrm{N}\right)$, nitrate-nitrogen $\left(\mathrm{NO}_{3}-\mathrm{N}\right)$, and dissolved phosphate $(\mathrm{mg} / \mathrm{L})$ concentrations were estimated as detailed in [63]. The total phosphorus and total nitrogen contents were determined as detailed in [64]. The dissolved phosphorus content was determined as described by [65].

\subsection{Azolla sp. Analysis}

\subsubsection{Chlorophyll Determination}

Measurement of chlorophyll a and b was conducted as described by [66].

\subsubsection{Proximate Analysis}

Samples of Azolla sp. plants were collected and analyzed to determine their moisture content \% (by drying in an oven at $105^{\circ} \mathrm{C}$ for $24 \mathrm{~h}$ ), ash \% (by ignition in a muffle furnace at $500{ }^{\circ} \mathrm{C}$ for $8 \mathrm{~h}$ ), and fat content $\%$ (ether extract by the Soxhlet system using petroleum ether), and the Kjeldalh nitrogen 
content was estimated using the Kjeldalh method. Then, obtained values were multiplied by 6.25 to obtain the protein content values [67].

\subsubsection{Growth Rate}

The total fresh biomass content in each pond was determined, and subsamples were taken for fresh weight and dry weight measurements. Fresh weight was determined by taking the plants out of the ponds and carefully blotting them dry on a paper towel before weighing them. The dry weight samples were washed in a sieve for $1 \mathrm{~min}$ while running demineralized water to remove adhered particles, and then the samples were put in paper bags in an oven for $48 \mathrm{~h}$ at $70{ }^{\circ} \mathrm{C}$. The doubling time $\left(D_{t}\right)$ and relative growth rate (RGR) expressed as $g / g$ per day were calculated using the formula reported by [68-70]:

$$
\mathrm{D}_{\mathrm{t}}=0.693 \mathrm{t} / \ln \left(\mathrm{B}_{\mathrm{f}} / \mathrm{B}_{\mathrm{o}}\right)
$$

where $B_{f}$ is the final biomass; $B_{o}$ is the initial biomass, and $t$ is the growth period.

$$
\mathrm{RGR}=\left(\ln \mathrm{B}_{2}-\ln \mathrm{B}_{1}\right) /\left(\mathrm{t}_{2}-\mathrm{t}_{1}\right)
$$

where $B_{1}$ and $B_{2}$ represent the plant biomass at times $t_{1}$ and $t_{2}$ of the sampling period.

\subsection{Statistical Analysis}

By assuming that there is no precise difference in each concrete pond, samples collected from each treatment per month can be considered as dependent samples. Therefore, for the three independent treatments (control, organic, and inorganic), one way ANOVA and the Duncan multiple range test [71] were used to test whether differences among treatments and time were significant at $p \leq 0.05$. Prior to ANOVA, data were tested for homogeneity using the Levene's test. All the considered variables showed homogeneity. Specific post hoc comparisons were performed using LSD. Correlation coefficients and Pearson correlations $(r$ ) between the different parameters were computed. Correlations and all statistical analyses were conducted using SPSS for windows, version 22 (SPSS, Richmond).

\section{Conclusions}

In sum, the application of different fertilizers has a respectable effect on Azolla sp. productivity and water physico-chemical properties since fertilization increases the chlorophyll and nutrient contents ( $\mathrm{N}$ and $\mathrm{P}$ ), as well as improves the biochemical composition and growth rate of Azolla $s p$. These parameters were highest following organic fertilizer treatment compared with inorganic treatment. This fertilizer may be added to Azolla sp. grown in ponds to enhance its nutrition value, which enhances the protein content. Therefore, Azolla pinnata can be used as an alternative feed to animal food.

Author Contributions: Conceptualization, E.A. and A.-f.S.S.; methodology, E.A. and A.-f.S.S.; software, E.A.; validation, E.A. and A.-f.S.S.; formal analysis, E.A.; investigation, E.A. and A.-f.S.S.; resources, E.A. and A.-f.S.S.; data curation, E.A. and A.-f.S.S.; writing-original draft preparation, E.A. and A.-f.S.S.; writing-review and editing, E.A.; visualization, E.A. and A.-f.S.S.; supervision, E.A. and A.-f.S.S. All authors have read and agreed to the published version of the manuscript.

Funding: This research received no external funding.

Acknowledgments: This work was carried out using the facilities and materials in the biotechnology laboratory of the Department of Biotechnology, Taif University and the Plant Biotechnology Laboratory of the Botany and Microbiology Department, Faculty of Science, Zagazig University.

Conflicts of Interest: The authors declare no conflict of interest. 


\section{References}

1. Munasinghe, J.; Dilhan, M.; Sundarabarathy, T. Utilization of aquatic plants: A method to enhance the productivity of water in seasonal tanks in the Anuradhapura District. Int. Water Manag. Inst. Conf. Pap. 2010, 1, 23. Available online: https://www.researchgate.net/publication/257653325 (accessed on 23 June 2020).

2. Bindraban, P.S.; Dimkpa, C.; Nagarajan, L.; Roy, A.; Rabbinge, R. Revisiting fertilisers and fertilisation strategies for improved nutrient uptake by plants. Biol. Fertil. Soils 2015, 51, 897-911. [CrossRef]

3. Boyd, C. Aquaculture pond fertilization. CAB Rev. Perspect. Agric. Vet. Sci. Nutri. Nat. Res. 2018, 13, 1-12. [CrossRef]

4. Senthil Murugan, A.; Prabhahar, C.; Saleshrani, K.; Tharmaraj, K.; Ashok Raja, C. Influence of different doses of fertilizer (nitrophos) on the growth performance of major carps-labeo rohita, catla catla, cirrhinus mrigala. Int. J. Recent Sci. Res. 2012, 3, 175-178. Available online: https://recentscientific.com/sites/default/ files/Download_177.pdf (accessed on 23 June 2020).

5. Jana, B.B. Distribution pattern and role of phosphate solubilizing bacteria in the enhancement of fertilizer value of rock phosphate in aquaculture ponds: State-of-the-art. In First International Meeting on Microbial Phosphate Solubilization; Velázquez, E., Rodríguez-Barrueco, C., Eds.; Springer: Dordrecht, The Netherlands, 2007; pp. 229-238. [CrossRef]

6. Metzger, R.; Boyd, C. Liquid Ammonium Polyphosphate as a Fish Pond Fertilizer. Trans. Am. Fish. Soc. 1980, 109, 563-570. [CrossRef]

7. Mischler, J.A.; Taylor, P.G.; Townsend, A.R. Nitrogen Limitation of Pond Ecosystems on the Plains of Eastern Colorado. PLoS ONE 2014, 9, e95757. [CrossRef]

8. Room, P.M.; Thomas, P.A. Nitrogen, phosphorus and potassium in Salvinia molesta Mitchell in the field: Effects of weather, insect damage, fertilizers and age. Aquat. Bot. 1986, 24, 213-232. [CrossRef]

9. Rascio, N.; La Rocca, N. Biological Nitrogen Fixation. In Reference Module in Earth Systems and Environmental Sciences; Elsevier: Amsterdam, The Netherlands, 2013. [CrossRef]

10. Tew, K.S.; Conroy, J.D.; Culver, D.A. Effects of lowered inorganic phosphorus fertilization rates on pond production of percid fingerlings. Aquaculture 2006, 255, 436-446. [CrossRef]

11. Mulyani, O.; Machfud, Y.; Setiawan, A.; Joy, B. Potential of local organic matters in Jatinangor West Java Indonesia as raw materials for organic fertilizer. IOP Conf. Ser. Earth Environ. Sci. 2019, 393, 012048. [CrossRef]

12. Azab, E. Effect of water stress and biological fertilization on maize growth, chemical composition and productivity in calcareous soil. Am. J. Plant Physiol. 2016, 11, 1-11. [CrossRef]

13. Aubry, E.; Dinant, S.; Vilaine, F.; Bellini, C.; Le Hir, R. Lateral Transport of Organic and Inorganic Solutes. Plants 2019, 8, 20. [CrossRef]

14. Reyes, T.G.; Crisosto, J.M. Characterization of Dissolved Organic Matter in River Water by Conventional Methods and Direct Sample Analysis-Time of Flight-Mass Spectrometry. J. Chem. 2016, 2016, 1537370. [CrossRef]

15. Kuzucu, M. Effects of organic fertilizer application on yield, soil organic matter and porosity on kilis oil olive variety under arid conditions. Eurasian J. For. Sci. 2019, 7, 77-83. [CrossRef]

16. Herold, N.; Schöning, I.; Michalzik, B.; Trumbore, S.; Schrumpf, M. Controls on soil carbon storage and turnover in German landscapes. Biogeochemistry 2014, 119, 435-451. Available online: https://www.jstor.org/ stable/24716905 (accessed on 23 June 2020). [CrossRef]

17. Ranalli, G.; Bottura, G.; Taddei, P.; Garavani, M.; Marchetti, R.; Sorlini, C. Composting of solid and sludge residues from agricultural and food industries. Bioindicators of monitoring and compost maturity. J. Environ. Sci. Health A 2001, 36, 415-436. [CrossRef]

18. Goyal, S.; Dhull, S.K.; Kapoor, K.K. Chemical and biological changes during composting of different organic wastes and assessment of compost maturity. Bioresour. Technol. 2005, 96, 1584-1591. [CrossRef]

19. Farahpour-Haghani, A.; Hassanpour, M.; Alinia, F.; Nouri-Ganbalani, G.; Razmjou, J.; Agassiz, D. Water ferns Azolla spp. (Azollaceae) as new host plants for the small China-mark moth, Cataclysta lemnata (Linnaeus, 1758) (Lepidoptera, Crambidae, Acentropinae). Nota Lepidopterol. 2017, 40, 1-13. [CrossRef]

20. Hemalatha, M.; Sravan, J.S.; Min, B.; Venkata Mohan, S. Concomitant use of Azolla derived bioelectrode as anode and hydrolysate as substrate for microbial fuel cell and electro-fermentation applications. Sci. Total Environ. 2019, 707, 135851. [CrossRef] [PubMed] 
21. Nayak, S.; Prasanna, R.; Pabby, A.; Dominic, T.K.; Singh, P.K. Effect of urea, blue green algae and Azolla on nitrogen fixation and chlorophyll accumulation in soil under rice. Biol. Fertil. Soils 2004, 40,67-72. [CrossRef]

22. Trindade, C.R.T.; Albertoni, E.F.; Palma-Silva, C. Temporal variation in the biomass and nutrient status of Azolla filiculoides Lam. (Salviniaceae) in a small shallow dystrophic lake. Acta Limnol. Bras. 2011, 23, 368-375. [CrossRef]

23. Lumpkin, T.A.; Plucknett, D.L. Azolla as a Green Manure: Use and Management in Crop Production; Westview Press: Boulder, CO, USA, 1982; p. 230. Available online: https://www.cabdirect.org/cabdirect/abstract/ 19831974184 (accessed on 23 June 2020).

24. Bhuvaneshwari, K.; Singh, P.K. Response of nitrogen-fixing water fern Azolla biofertilization to rice crop. 3 Biotech 2015, 5, 523-529. [CrossRef] [PubMed]

25. Arora, A.; Singh, P.K. Comparison of biomass productivity and nitrogen fixing potential of Azolla spp. Biomass Bioenergy 2003, 24, 175-178. [CrossRef]

26. Bocchi, S.; Malgioglio, A. Azolla-Anabaena as a Biofertilizer for Rice Paddy Fields in the Po Valley, a Temperate Rice Area in Northern Italy. Int. J. Agron. 2010, 2010, 152158. [CrossRef]

27. Setiawati, M.R.; Damayani, M.; Herdiyantoro, D.; Suryatmana, P.; Anggraini, D.; Khumairah, F.H. The application dosage of Azolla pinnata in fresh and powder form as organic fertilizer on soil chemical properties, growth and yield of rice plant. AIP Conf. Proc. 2018, 1927, 030017. [CrossRef]

28. Raja, W.; Rathaur, P.; John, S.; Ramteke, P. Azolla: An aquatic pteridophyte with great potential. Int. J. Res. Biol. Sci. 2012, 2, 68-72. Available online: https://www.researchgate.net/publication/307632413_Azolla_An_ aquatic_pteridophyte_with_great_potential (accessed on 23 June 2020).

29. Fiogbé, E.D.; Micha, J.-C.; Van Hove, C. Use of a natural aquatic fern, Azolla microphylla, as a main component in food for the omnivorous-phytoplanktonophagous tilapia, Oreochromis niloticus L. J. Appl. Ichthyol. 2004, 20, 517-520. [CrossRef]

30. Shiomi, N.; Kitoh, S. Culture of Azolla in a pond, nutrient composition, and use as fish feed. Soil Sci. Plant Nutr. 2001, 47, 27-34. [CrossRef]

31. Azab, E.; Hegazy, A.K.; El-Sharnouby, M.E.; Abd Elsalam, H.E. Phytoremediation of the organic Xenobiotic simazine by p450-1a2 transgenic Arabidopsis thaliana plants. Int. J. Phytoremediat. 2016, 18, 738-746. [CrossRef] [PubMed]

32. Hegazy, A.K.; Emam, M.H.; Lovett-Doust, L.; Azab, E.; El-Khatib, A.A. Response of duckweed to lead exposure: Phytomining, bioindicators and bioremediation. Desalin. Water Treat. 2017, 70, 227-234. [CrossRef]

33. Azab, E.; Kebeish, R.; Hegazy, A.K. Expression of the human gene CYP1A2 enhances tolerance and detoxification of the phenylurea herbicide linuron in Arabidopsis thaliana plants and Escherichia coli. Environ. Pollut. 2018, 238, 281-290. [CrossRef]

34. Kebeish, R.; Azab, E.; Peterhaensel, C.; El-Basheer, R. Engineering the metabolism of the phenylurea herbicide chlortoluron in genetically modified Arabidopsis thaliana plants expressing the mammalian cytochrome P450 enzyme CYP1A2. Environ. Sci. Pollut. Res. Int. 2014, 21, 8224-8232. [CrossRef]

35. Sood, A.; Uniyal, P.; Prasanna, R.; Ahluwalia, A. Phytoremediation Potential of Aquatic Macrophyte, Azolla. Ambio 2012, 41, 122-137. [CrossRef] [PubMed]

36. Liu, X.; Min, C.; Xia-shi, L.; Chungchu, L. Research on some functions of Azolla in CELSS system. Acta Astronaut. 2008, 63, 1061-1066. [CrossRef]

37. Wagner, G.M. Azolla: A review of its biology and utilization. Bot. Rev. 1997, 63, 1-26. [CrossRef]

38. Temmink, R.J.M.; Harpenslager, S.F.; Smolders, A.J.P.; van Dijk, G.; Peters, R.C.J.H.; Lamers, L.P.M.; van Kempen, M.M.L. Azolla along a phosphorus gradient: Biphasic growth response linked to diazotroph traits and phosphorus-induced iron chlorosis. Sci. Rep. 2018, 8, 4451. [CrossRef] [PubMed]

39. Toledo, J.; Penha, J. Performance of Azolla caroliniana Willd. and Salvinia auriculata Aubl. on fish farming effluent. Braz. J. Biol. 2011, 71, 37-45. Available online: http://www.scielo.br/scielo.php?script=sci_arttext\& pid=S1519-69842011000100007\&nrm=iso (accessed on 23 June 2020). [CrossRef]

40. Boyd, C.E. Water Quality in Ponds for Aquaculture; Alabama Agricultural Experiment Station, Auburn University: Auburn, AL, USA, 1990; Available online: https://books.google.com.sa/books?id= oVY5AQAAIAAJ (accessed on 23 June 2020).

41. Utomo, R.; Noviandi, C.T.; Umami, N.; Permadi, A. Effect of Composted Animal Manure as Fertilizer on Productivity of Azolla Pinnata Grown in Earthen Ponds. OnLine J. Biol. Sci. 2019, 19, 232-236. [CrossRef] 
42. Kumar, M.S.; Binh, T.T.; Burgess, S.N.; Luu, L.T. Evaluation of Optimal Species Ratio to Maximize Fish Polyculture Production. J. Appl. Aquac. 2005, 17, 35-49. [CrossRef]

43. Ma, C.; Ban, T.; Yu, H.; Li, Q.; Li, X.; Jiang, W.; Xie, J. Urea Addition Promotes the Metabolism and Utilization of Nitrogen in Cucumber. Agronomy 2019, 9, 262. Available online: https://www.mdpi.com/2073-4395/9/5/262 (accessed on 23 May 2019). [CrossRef]

44. Wudtisin, W.; Boyd, C.E. Determination of the phosphorus fertilization rate for bluegill ponds using regression analysis. Aquac. Res. 2005, 36, 593-599. [CrossRef]

45. Das, P.C.; Ayyappan, S.; Jena, J. Comparative changes in water quality and role of pond soil after application of different levels of organic and inorganic inputs. Aquac. Res. 2005, 36, 785-798. [CrossRef]

46. Kamal, S.M.; Ghanny, S.A.; Abd-El All, M.M. Effect of nutrition and fertilization on production of Nile tilapia (O. niloticus) fingerlings in concrete ponds. Aquafish Collaborative Research Support Program: Corvallis, Proceedings of The 8th International Symposium on Tilapia in Aquaculture, Cairo, Egypt, 12 October 2008; pp. 387-401. Available online: https://www.cabdirect.org/cabdirect/abstract/20133318721 (accessed on 23 June 2020).

47. Brown, T.W.; Boyd, C.E.; Chappell, J.A. Organic Carbon and Dissolved Oxygen Budgets for a Commercial-Size, In-pond Raceway System. J. World Aquac. Soc. 2015, 46, 539-548. [CrossRef]

48. Huang, W.; Shao, H.; Li, W.; Jiang, H.S.; Chen, Y.-Y. Effects of urea on growth and photosynthetic metabolism of two aquatic plants (Cabomba caroliniana A. Gray and Elodea nuttallii (Planch.) H. St. John). Aquat. Bot. 2017, 140, 66-77. [CrossRef]

49. Alizade, A.; Nejad, T.; Rafiee, M. Effect of plant density on percent of remobilization, chlorophyll content, light penetration rate and effective grain filling period of chickpea (Cicer arietinum) in dry farming. Life Sci. J. 2011, 8, 36-39.

50. Ren, B.; Liu, W.; Zhang, J.; Dong, S.; Liu, P.; Zhao, B. Effects of plant density on the photosynthetic and chloroplast characteristics of maize under high-yielding conditions. Sci. Nat. 2017, 104. [CrossRef]

51. Hazary, M. Effect of Nitrogen and Phosphorus Fertilizer on Yield and Nutritional Quality of Jumbo Grass (Sorghum Grass x Sudan Grass). Adv. Anim. Vet. Sci. 2015, 3, 444-450. [CrossRef]

52. Handajani, H. Optimation of Nitrogen and Phosphorus in Azolla Growth as Biofertilizer. Makara J. Technol. 2012, 15, 142-146. Available online: http://journal.ui.ac.id/technology/journal/article/view/931 (accessed on 23 June 2020). [CrossRef]

53. Sanginga, N.; Van Hove, C. Amino acid composition of azolla as affected by strains and population density. Plant Soil 1989, 117, 263-267. [CrossRef]

54. Sadeghi, J.; Zarkami, R.; Sabetraftar, K.; Van Damme, P. A review of some ecological factors affecting the growth of Azolla spp. Casp. J. Environ. Sci. 2013, 11, 65-76. Available online: http://hdl.handle.net/1854/LU-4104609 (accessed on 23 June 2020).

55. Kösesakal, T. Effects of Seasonal Changes on Pigment Composition of Azolla filiculoides Lam. Am. Fern J. 2014, 104, 58-66. [CrossRef]

56. Wheeler, P.A.; Björnsäter, B.R. Seasonal fluctuations in tissue nitrogen, phosphorus, and n:P for five macroalgal species common to the pacific northwest coast1. J. Phycol. 1992, 28, 1-6. [CrossRef]

57. Lourenço, S.O.; Barbarino, E.; Nascimento, A.; Freitas, J.N.P.; Diniz, G.S. Tissue Nitrogen and Phosphorus in Seaweeds in a Tropical Eutrophic Environment: What a Long-Term Study Tells Us. J. Appl. Phycol. 2006, 18, 389-398. [CrossRef]

58. Costa, M.L.; Santos, M.C.; Carrapiço, F. Biomass Characterization of Azolla Filiculoides Grown in Natural Ecosystems and Wastewater; Springer: Dordrecht, The Netherlands, 1999; pp. 323-327. [CrossRef]

59. Richmond, A.E. Handbook of Microalgal Mass Culture; CRC Press: Boca Raton, FL, USA, 1986. [CrossRef]

60. Menéndez, M.; Herrera, J.; Comín, F.A. Effect of nitrogen and phosphorus supply on growth, chlorophyll content and tissue composition of the macroalga Chaetomorpha linum (O.F. Müll), Kütz, in a Mediterranean Coastal Lagoon. Sci. Mar. 2002, 66, 355-364. [CrossRef]

61. Chainark, S.; Boyd, C.E. Water and Sediment Quality, Phytoplankton Communities, and Channel Catfish Production in Sodium Nitrate-Treated Ponds. J. Appl. Aquac. 2010, 22, 171-185. [CrossRef]

62. Boyd, C.; Thunjai, T. Aquaculture Pond Bottom Soil Quality Management; Pond Dynamics/Aquaculture Collaborative Research Support Program: Corvallis, OR, USA, 2002. 
63. Greenberg, A.E.; Trussell, R.R.; Clesceri, L.S. Standard Methods for the Examination of Water and Wastewater; American Public Health Association; American Water Works Association; Water Pollution Control Federation; APHA: Washington, DC, USA, 1985; Available online: https://agris.fao.org/agris-search/search.do?recordID= US19890081964 (accessed on 23 June 2020).

64. Gross, A.; Boyd, C.E. A Digestion Procedure for the Simultaneous Determination of Total Nitrogen and Total Phosphorus in Pond Water. J. World Aquac. Soc. 1998, 29, 300-303. [CrossRef]

65. Radke, M.G.; Schneider, M.D.; Houghtaling, D.G. Dry weight, nitrogen and phosphorus content of Schistosoma mansoni. Exp. Parasitol. 1957, 6, 202-207. [CrossRef]

66. El-Sharnouby, M.E.; Azab, E.; Alotaibi, S.S.; Saleh, D. Influence of air temperature and soil moisture on growth and chemical composition of geranium plants. Pak. J. Bot. 2019, 51, 97-102. [CrossRef]

67. Association of Official Analytical, C.; Helrich, K. Official Methods of Analysis of the Association of Official Analytical Chemists; The Association: Arlington, VA, USA, 1990.

68. Badayos, R.B. Azolla: Its Culture, Management and Utilization in the Philippines. In Philippine Azolla Extension Program; National Azolla Action Program: Los Baños, Philippines, 1989; pp. 275-282.

69. Hechler, W.D.; Dawson, J.O. Factors affecting nitrogen fixation in Azolla caroliniana. Trans. Ill. State Acad. Sci. 1995, 88, 97-107. Available online: http://ilacadofsci.com/wp-content/uploads/2013/08/088-11MS9419print.pdf (accessed on 23 June 2020).

70. Hoffmann, W.; Poorter, H. Avoiding Bias in Calculations of Relative Growth Rate. Ann. Bot. 2002, 90, 37-42. [CrossRef]

71. Duncan, D.B. Multiple range and multiple F tests. Biometrics 1955, 11, 1-41. Available online: https: //www.jstor.org/stable/pdf/3001478.pdf?seq=1 (accessed on 23 June 2020). [CrossRef]

(C) 2020 by the authors. Licensee MDPI, Basel, Switzerland. This article is an open access article distributed under the terms and conditions of the Creative Commons Attribution (CC BY) license (http://creativecommons.org/licenses/by/4.0/). 